GIS - 理論と応用

Theory and Applications of GIS, 2007, Vol.15, No.2, pp.75-80

【研究・技術ノート】

\title{
2 次元ポリゴン解析ツールの開発とその利用例
}

\section{梅津 健一 \\ Development of two dimensional polygon analysis tool and example of its usage}

Ken-ichi UMEZU

\begin{abstract}
In recent days, we usually analyze polygon objects using applications of GIS and $\mathrm{CAD}$ in the civil engineering. For example, in urban design, we draw polygons with lot of lines and link them with land information, person information, and the negotiation records. It aims at the cost reduction business and the efficiency improvement of the business. Now, there are many GIS and CAD applications, however, most of them are too expensive. Therefore we have developed polygon analysis tool by VB (Visual Basic) and we have analyzed gravel polygons using this tool. In this report, we describe two dimensional polygon analysis tool and we show an example of its usage for investigating the grain size distribution of river gravels.
\end{abstract}

Keywords: ポリゴン解析 (polygon analysis), 河床磁 (river gravel), DXF (Data eXchange Format), VB (Visual Basic), デジタルオルソフォト (Digital Ortho Photo)

\section{1.はじめに}

土木設計の分野において，各種図面作成や設計業 務の管理に GIS や CAD のアプリケーションを用い てポリゴンオブジェクトを作図し利活用することが 多くなった。例えば都市計画や区画整理などの分野 では筆界のポリゴンと土地情報や地権者情報，交渉 記録などの膨大なテキスト情報をリンクさせ，設計 業務のコストダウンや業務の効率化を目指している （梅津，2000）。また砂防の分野では土石流危険区域 のポリゴンと災害履歴やデジタル写真などの情報 をリンクさせ, 仃舎内での情報閲覧（堀内・水山, 2005)のみならず,一部の情報を市民へインターネッ 卜配信（財団法人岐阜県建設研究センター, 2004） も行っているようである。このようにポリゴンオブ ジェクトの利活用は土木設計の分野において現在で

梅津：岐皁大学大学院連合農学研究科

United Graduate School of Agricultural Science,

Gifu University

于 501-1193 岐阜県岐阜市柳戸 1-1

E-Mail : k6102002@edu.gifu-u.ac.jp
は日常的になっており，今日さまざまな作図ッール や支援システムなどが開発され実用化されている。 しかしその多くはいまだに高価格であり，ユーザー のさまざまな要求を満たすようなアプリケーション は笑務で使用している立場から言えば依然少ないと 考える。このような現状から GISやCAD アフリケー ションを実務で使用する場合, 個人の細やかな要求 や用途にあった解析ツールは，市販の製品を購入す るより独自に開発したほうが早くまた経済的で便利 な場合がある。本レビューでは河床礫の粒径分布調 査の案件においてポリゴンの解析を要求され，筆者 が独自にプログラムを開発し実用化した例について 報告する。

\section{2. 河床磷の粒径分布調査とは}

河床碟の粒径分布調査とは，地学や土木などの分 野において自然河川に堆積している河床礫の大きさ を測り，河床礫の流送や堆積過程などについて検討 するための調查法の一つである。この測定には古く 
から調查地においてノギスなどの計測器具を用いて 個々の河床砂を手作業で測定していたが，計測技術 の発達などによって，今日ではデジタル技術を用い た写真測定法による粒径分布調查が行われるように なってきた。中でも内尾ら（2005）は独自の優れた 画像処理技術と解析装置を開発し，一般に市販まで 行っているようである。しかし巨磁のような大磁径 の測定には，装置の高度限界から不向きであり課題 を抱えている。そこで梅津・戸松（2007）はそれら の課題を改善するため, 低高度空中写真の空撮技術 を粒径分布調查に応用し，写真精度の検証と実用性 について報告を行っている。そこでデジタル技術を 用いた河床碟の粒径分布調查を行うため，筆者が解 析部分にポリゴン解析ツールを独自に開発し，その 技術を用いて実際に現地での利用を行った例につい てここで報告する。

ところで河床碟の測定は図 1 に示すように, 河床 磂の表面上で最も離れている点どうしを結んだ線を 長軸，長軸と直交して砂の表面を結ぶ線のうち，最 も長い線を中間軸, 中間軸と長軸がつくる面と直交 する線のうち最も長い線を短軸とし，それぞれの長 さを長径，中間径，短径と呼んでいる（公文·立石， 1998）。ここでは表層のみの調查案件という理由か らポリゴン解析ッールによって解析を行うのは長軸 と中間軸のみで, 2 次元の解析を行うこととする。 解析ツールでは長軸, 中間軸の位置座標, 長径, 中 間径の距離, 河床砂の面積を求めることを目的に開 発を行った。

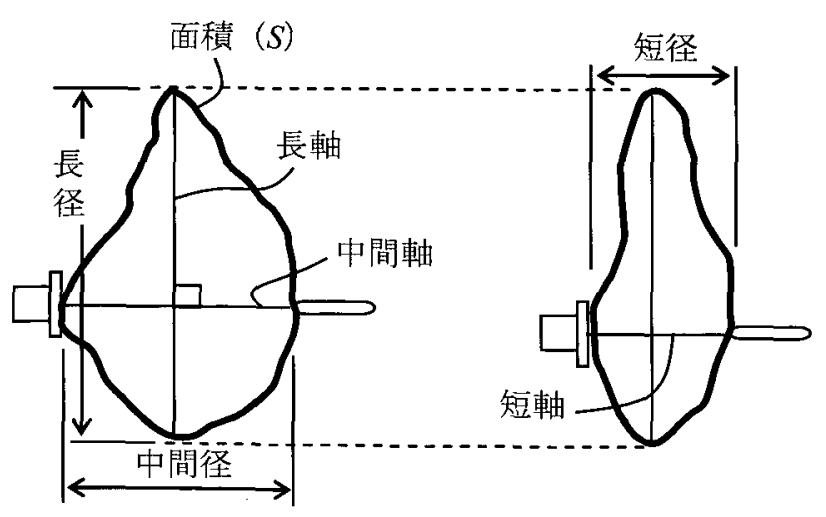

図 1 河床䃯の粒径調査の調査項目

\section{3. ポリゴン解析ツールの仕組み}

\section{1. 現地での写真撮影の方法と画像処理}

河床碩のポリゴン解析を行うためには, 現地にお いて河床表層の精度の高いデジタル写真を撮影する 必要がある。そこで図 2 に示す延長ポールに 2 基の 民生用デジタルスチルカメラを搭載した撮影方法 で，現地において撮影を行った。図に示している中 心の延長ポールの素材はグラスファイバー性の物を 使用し，延長ポールの高さは可変式であるが本報 告では調查地の状況から最適な值を約 $5 \mathrm{~m}$ とした。 デジタルカメラの設置は延長ポールの先端に左右に 伸ばしたアルミパイプ（口径 $1 \mathrm{~cm}$ ，長さ $1 \mathrm{~m}$ ）にア ルミ製 $\mathrm{L}$ 字型金具を特別に加工し固定した。ここ では，構造上のバランスを保つ目的と撮影範囲を広 く得るためステレオカメラとした。またデジタルカ メラは写真精度を確保するため, 1000 万画素の記 録媒体を持つ最新の民生用デジタルスチルカメラを 使用し撮影を行った。その後撮影したラスター画像 を研究室へ持ち帰り $\mathrm{PC}$ 上で最適化，レンズの歪曲 収差を行い,アフィン変換で幾何補正しデジタルオ ルソフォトとした。

\section{2. 処理フロー}

河床礫の輪郭は図 1 に示したように，PC 上で独 立した個々の閉じたべクターポリゴンオブジェクト として描画できる。そこで河床礫の解析は河床砂の 輪郭をあらかじめポリゴンオブジェクトとして作図 しておき，そのオブジェクトの座標点から目的とす

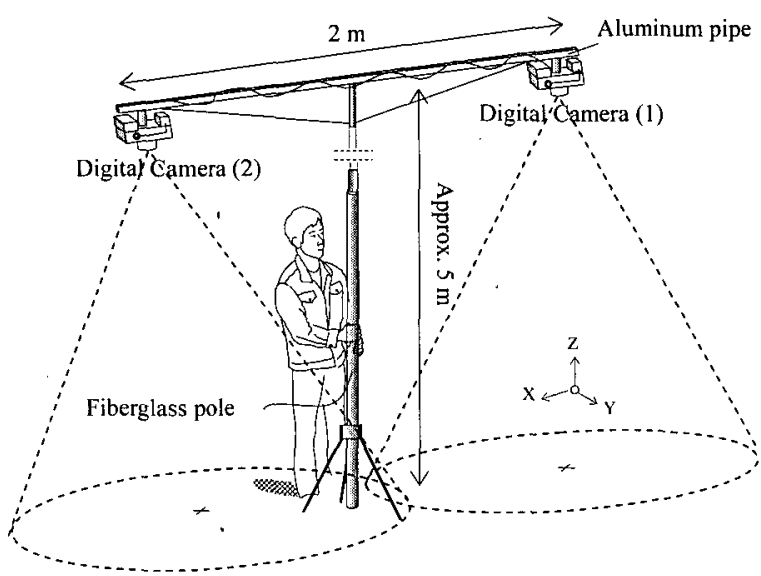

図 2 ステレオカメラによる垂直写真の撮影方法 
る計算值を算出する処理フローとした。処理フロー は図 3 に示すように，まず現地で撮影した河床礫の 平面写真からデジタルオルソフォトを作成し, GIS や $\mathrm{CAD}$ ベースのアプリケーションを用いてそのデ ジタルオルソフォトをベースに河床礫のベクターポ リゴンオブジェクトを作図する。そしてポリゴンオ ブジェクトの 2 次元位置座標 $(x, y)$ を DXF（Data eXchange Format）形式（落合, 2003）で読み込み, 作図したポリゴンの座標データを用いて座標計算を 行い, 結果の描画や計算結果の出力を行う仕組みと した。算出された長軸と中間軸の描画は DXF 形式 とし、ポリゴン内に長軸と中間軸をそれぞれ描画す ることとした。ポリゴン解析ツールは Visual Basic で作成し，図 4 に示すように単一のダイアログボッ クスで，開くアイコンをクリックすることにより， DXF 形式のファイルを読み込み, 保存ボタンをク リックすることにより, 解析結果を DXF, TXTの 2 つのファイルとして保存するインタフェースとし た。

\section{3. 計算方法}

長軸の座標計算は以下の通りである。ここで任意 のポリゴンオブジェクトにおける頂点数を $n$ とす

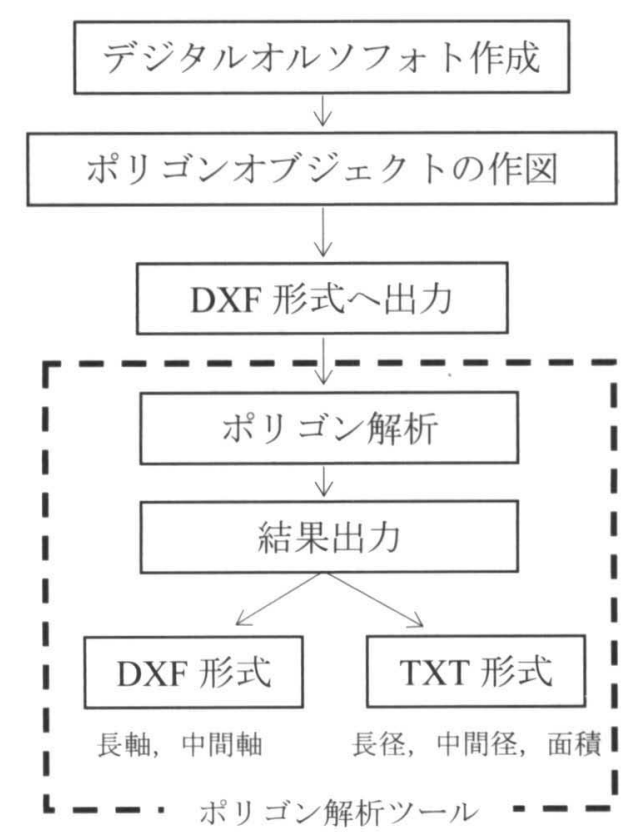

図 3 ポリゴン解析ツールの処理フロー

\section{Polygon Analyize $-\square \times$ 피미

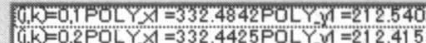 \\ (GK $=0.3 \mathrm{POL} Y X=332.4911 \mathrm{POL} Y Y \mathrm{Y}=212.3182$ \\ $, Y=0,4 \mathrm{POL} Y A=332.5883 \mathrm{POL} Y \mathrm{Y}=21.3276$ \\ $\mathrm{k})=0.5 \mathrm{POL} Y X \mid=332.7757 \mathrm{POL} Y \mathrm{Y}=212.1934$ \\ $(0, k)=0,6 \mathrm{POL} Y X 1=332.9493 \mathrm{POL} Y, Y 1=212.0893$ \\ $(\hat{G}, k)=0.7 \mathrm{POL} Y X \mid=333.0742 \mathrm{POL} Y, Y A=212.0061$ \\ PolygonTotal $=\longdiv { 2 6 5 }$ Non $=$

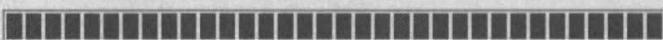

図 4 ポリゴン解析ツールのダイアログ

ると, ポリゴン内のすべての頂点は座標行列 $\left(x_{11}\right.$, $\left.y_{11}\right),\left(x_{12}, y_{12}\right) \cdots\left(x_{m n}, y_{m n}\right)$ と示される。このこと から, 座標行列を (1) 式の距離行列に変換し, 最長 軸径となる座標の組合せを, ここでは長軸座標とし た。

$\left[\begin{array}{cccc}x_{11}, y_{11} & x_{12}, y_{12} & \cdots x_{1 n}, y_{1 n} \\ x_{21}, y_{21} & x_{22}, y_{22} & \cdots x_{2 n}, y_{2 n} \\ \vdots & \vdots & \ddots & \vdots \\ x_{m 1}, y_{m 1} & x_{m 2}, y_{m 2} & \cdots x_{m n}, y_{m n}\end{array}\right]$

次に（1）式より求めた長軸の座標から, 長軸の 直線式 $a x+b y=p$ を算出すれば中間軸の傾きは $-1 / a$ となり，ポリゴン内に交点を持つため, 中間軸の直 線式 $-1 / a x+c y=q$ が求まる。ポリゴン演算処理に より得られた中間軸のデータは, Wentworthの階 級区分（公文・立石，1998）により分類し粒径加積 曲線（図 7）を作成した。

一般に河床敕の粒径分布調査には (2) 式を用いて 河床砂の 3 軸径から推定体積を一旦算出し, 碟比重 を用いて重量百分率を算出することとなっているが (公文・立石, 1998), 今回はポリゴンオブジェクト の座標行列から (3) 式の多角形の面積公式を用いて 面積 $(S)$ を算出し, 中間軸の各階級で集計し面積 百分率の算出を行った。ここで $V$ : 体積, $W$ :重さ, $a$ : 長軸, $b$ : 中間軸, $c$ : 短軸, $\rho$ : 礫比重, $n:$ 頂点 数, $x, y$ は頂点座標をそれぞれ示す。但し $x_{n+1}=x_{1}$, $y_{n+1}=y_{1}$ である。

$$
\begin{aligned}
& V=c^{2}(a b)^{1 / 2}, W=V \rho \\
& S=\frac{1}{2} \sum_{i=1}^{n}\left(x_{i}-x_{i+1}\right)\left(y_{i}-y_{i+1}\right)
\end{aligned}
$$




\section{4. 粒径分布調査への利用と結果}

\section{1.フィールドでの調查と結果}

フィールドは図 5 に示す岐阜県にある揖斐川中流 部の河川敷とした。調查は従来の調査方法と比較す るため図 2 の写真撮影と同時に計測器具を用いて 個々の河床砂の長径, 中間径, 短径の測定を行っ た。調查範囲は任意に選んた $2 \mathrm{~m} \times 2 \mathrm{~m}$ の格子内を 対象とし表層のみの河床礫をそれぞれの方法で調査 した。写真撮影では標定点とするため $1 \mathrm{~m}$ の標尺 を河床磁と同時に撮影した。

フィールドでの調査の結果, 今回の写真撮影の方 法は従来の方法と比べ, 現地での作業は写真撮影の みであるため, 調査労力を大きく軽隇することが分 かった。特に大粒径の場合では重量がかさみ，実測 での調査が困難となるため, 写真撮影のみの今回の 方法は現地での作業に非常に有効であることが分 かった。また今回の方法は非常に簡便であるため, 一度に複数地区の調査にも適用可能である。

\section{2. ポリゴン解析ツールでの解析と結果}

前節で撮影された写真を実験室へ持ち帰り, 撮影 された写真に幾何補正の処理を施しデジタルオル ソフォトに加工した。その後河床磁の輪郭を汎用 $\mathrm{CAD}$ である Autodesk 社の AutoCAD を用いてオぺ レータがディスプレイ上で判読しポリゴンオブジェ クトを作図した。河床礫の輪郭の判読は河床礫どう しが判別可能なものだけとし，不鮮明なものや重 なったものは省くこととした。ポリゴン解析の結果 を図 6 に示すように，作図したすべてのポリゴンオ ブジェクトの長軸, 中間軸を算出し、これらを明瞭 に描画することができた。ここで円に交わる線が中 間軸で, 中間軸に直交する線が長軸を示している。 図 6 は今回の調査方法で 520 個の河床鿬を解析した 結果であり，調査から結果算出までに必要とされた 時間は約 1 時間程度である。通常これだけの河床碟 を調査する場合，これまでの著者らの経験から現地 での実測だけでも確実に 2 時間以上は必要である。 そのため今回の調査方法は, 調査から結果算出まで に必要とされるすべての作業時間をこれまでの方法 の約半分以下にまで短縮することが可能である。

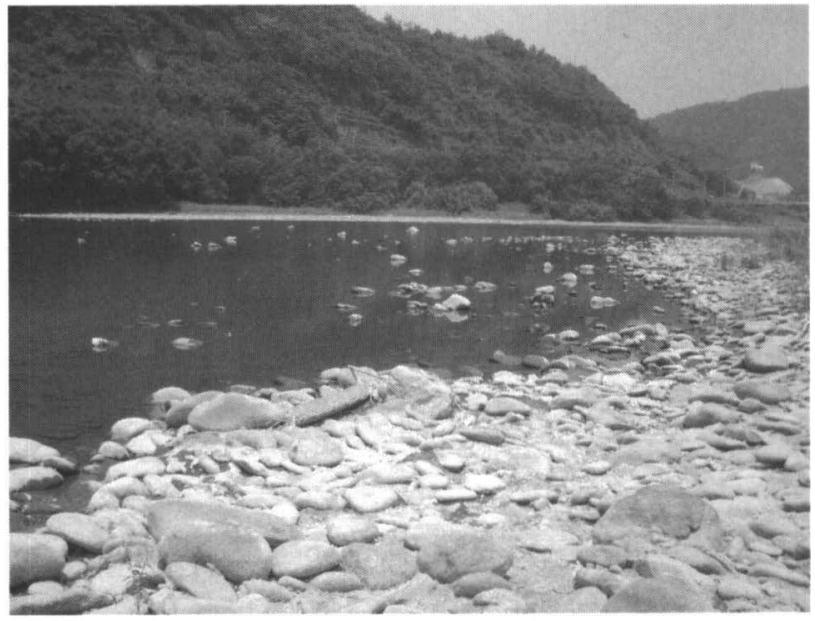

図 5 調查地の写真

次に従来の調査方法とポリゴン解析の結果を図 -7 の粒径加積曲線で示す。ここで従来の方法と今回の 方法ともほほ似たような曲線の波形を示している。 また今回の方法の值は, 実測の平均粒径（d50）の $\pm 10 \mathrm{~mm}$ の範囲内に収まっている。このためポリ ゴン解析を用いた今回の方法の解析結果は精度を確 保しており，実際の調査に用いても遜色ないことが 明らかとなった。しかし今回の方法ではポリゴンオ ブジェクトの判読や作図作業が新たに必要となった が，それでも従来の方法よりはトータルの作業時間 が約半分と短く，河床礫の粒径分布調查に有効であ ることが明らかとなった。

\section{5. 結語}

河床砂の調査はこれまでおよそ 100 年に渡り行わ れ，技術が発達している今日でも従来の計測器具を 用いて行っていることが多く、フィールド調査にお いて多大な労力と時間を要することが懸念されてい た。今回この調査に関わる労力と時間の軽減を目的 にポリゴン解析ッールを開発し，ここでの解析結果 から実務上の精度を確保していることが明らかとな り，研究目的は達成したと考えている。また従来の 粒径分布調査では河川中上流部など大きな粒径に なった場合，礫を片手で持つことが困難となり実測 自体が不可能となることがあるが，今回の方法では 現地での調査は写真撮影のみで済み非常に簡便であ ることから粒径分布調査に非常に有効であることが 

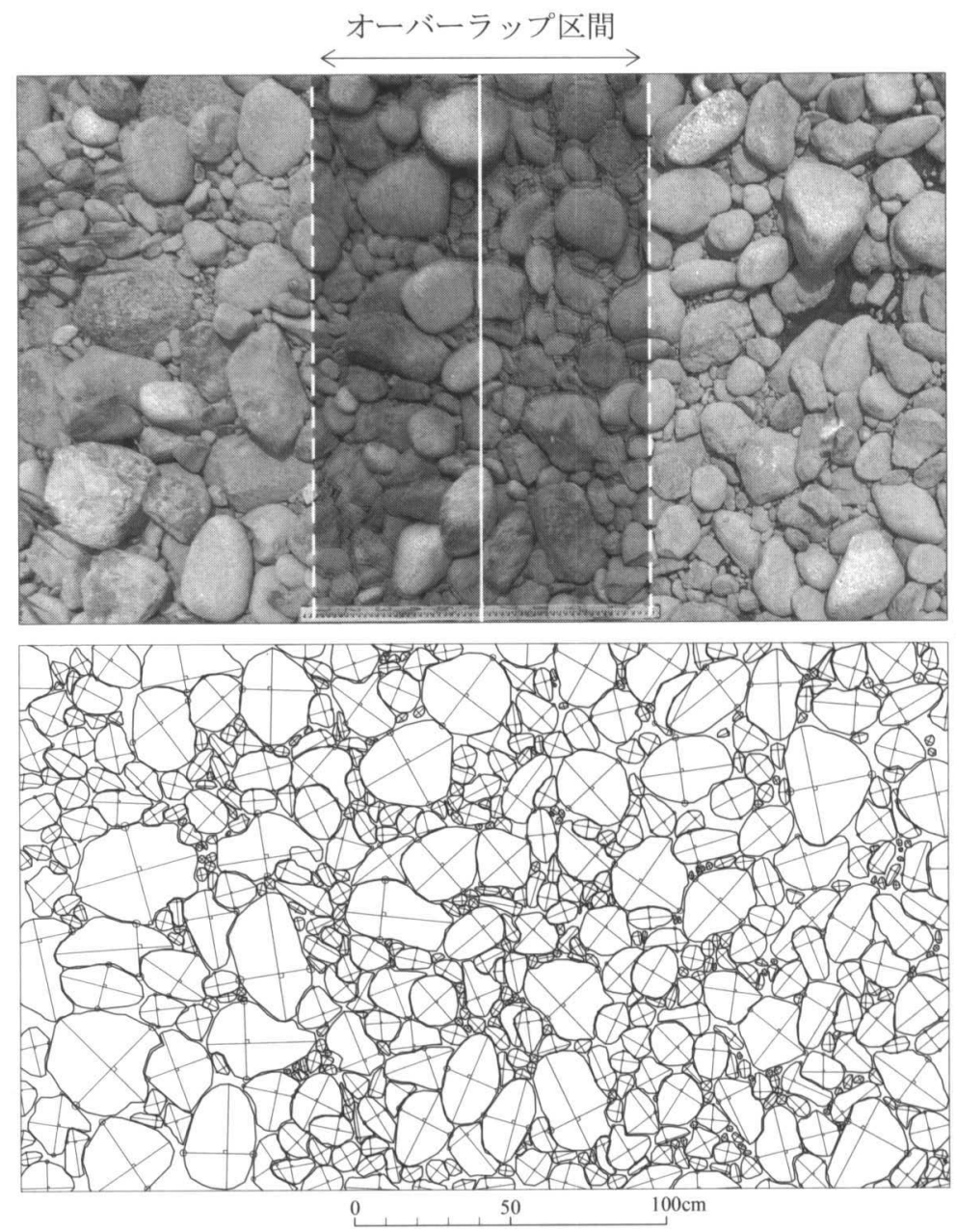

図 6 ポリゴン解析の結果, 上 : 解析前, 下 : 解析後

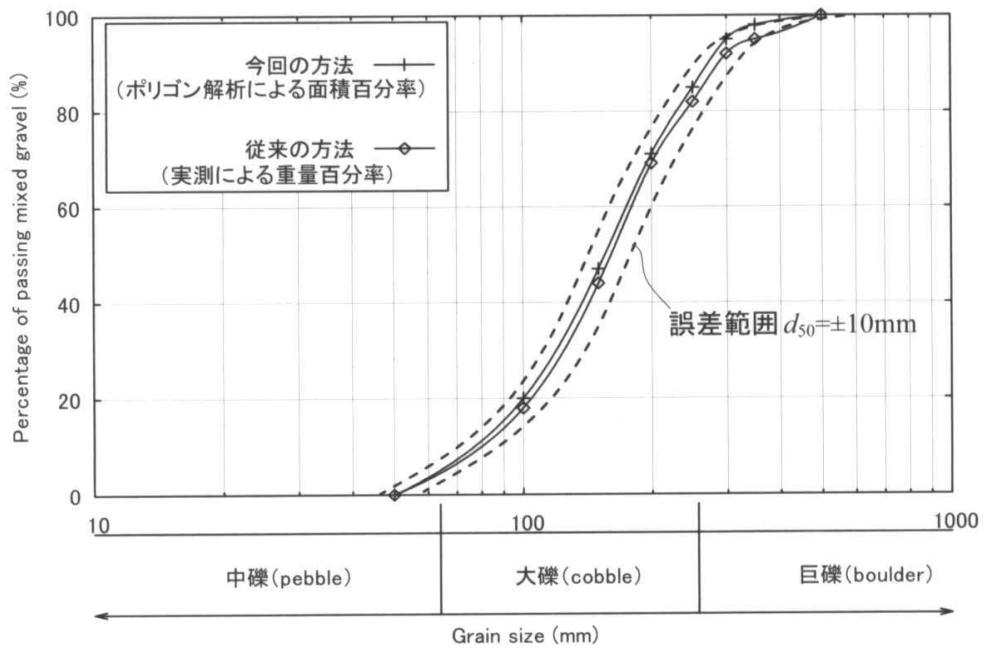

図 7 粒径加積曲線 
分かった。

しかし対象とする調査地の状況など，いくつかの要 因によっては得られる数值に影響を及ぼす恐れがあ るため注意が必要である。以下に今後調查研究が必 要と考える課題についてまとめた。

・重なり合った礫や下層の礫の取り扱い

・覆瓦構造（imbricate structure）のように地表に 対して平行でない礫の場合の観測誤差

・幾何補正の補点数が少ない場合など，加工技術 によっては真值から乘離することがあること

・河床の縦横断形状や地表の凹凸による観測誤差

・使用するカメラレンズの歪誤差

\section{参考文献}

内尾政人 ·横山康二 - 中川一 ·上杉満昭 - 沢田豊明 - 福 田義徳 (2005) 画像処理方式による硶床河川の粒度分 布測定装置の開発.「砂防学会誌」，58 (2)，26-31.

梅津健一（2000）IT（情報技術）による区画整理事業の円 滑な推進.「区画整理フォーラム 2000 第 2 分科会」, 44-45.

梅津健一・戸松修（2007）低高度空中写真に上る河床碩 調査法の精度検証と実用性について。砂防学会誌」, 60 (1) , 19-28.

落合重紀 (2003)『DXF ハンドブック』，オーム社 .

公文富士夫・立石雅昭（1998）『新版屑砕物の研究法』, 地学団体研究会.

財団法人岐皁県建設研究センター (2004) 県域統合型 GIS ぎふ< http://www.gis.pref.gifu.jp/ >.

堀内成郎・水山高久 $(2005)$ 砂防管理関係情報の適切な管 理と有効活用.「平成 17 年度砂防学会研究発表会概 要集」, 196-197. 